\title{
АДМІНІСТРАТИВНО-ПРАВОВИЙ СТАТУС СУБ' ЄКТІВ ПУБЛІЧНОЇ АДМІНІСТРАЦІї, ЯКІ ЗДІЙСНЮЮТЬ ЗАПОБІГАННЯ ТА ПРОТИДІЮ ДОМАШНЬОМУ НАСИЛЬСТВУ
}

Манжос Н. В.

Мета статmі полягає в тому, щоб на основі цінностей природного права, теорії адміністративного права, чинного законодавства розкрити адміністративно-правовий статус суб'єктів публічної адміністрації, які здійснюють запобігання та протидію домашньому насильству в Україні. У статті розкрито адміністративно-правовий статус суб'єктів публічної адміністрації у сфері запобігання та протидії домашньому насильству. Він полягає в сукупності їхніх адміністративних обов'язків (завдань) і прав, порядку та підстав виникнення спеціальної правосуб' єктності та адміністративної відповідальності за зловживання публічною владою чи неналежне виконання наданої їм владної компетенції щодо недопущення, запобігання, протидіі та усунення шкоди, завданої домашнім насильством. 3'ясовано, що до спеціалізованих служб підтримки постраждалих осіб належать притулки для постраждалих осіб, центри медико-соціальної реабілітації постраждалих осіб, кол-центри з питань запобігання та протидії домашньому насильству, насильству за ознакою статі та насильству стосовно дітей, мобільні бригади соціально-психологічної допомоги постраждалим особам та особам, які постраждали від насильства за ознакою статі, а також заклади та установи, призначені виключно для постраждалих осіб та осіб, які постраждали від насильства за ознакою статі. Визначено, що юридична відповідальність суб'єктів публічної адміністрації за зловживання публічною владою чи неналежне виконання наданої їм владної компетенції $\epsilon$ стандартною і неконкретною, а саме: посадові та службові особи, визнані винними в порушенні вимог законодавства у сфері запобігання та протидіі домашньому насильству, несуть відповідальність відповідно до закону, постраждала особа та кривдник мають право на оскарження рішень, дій чи бездіяльності суб'єктів, що здійснюють заходи у сфері запобігання та протидії домашньому насильству, в порядку, встановленому законодавством. Іншими словами, посадові особи, суб'єкти публічної адміністрації, які здійснюють запобігання та протидію домашньому насильству, можуть бути притягнуті до спеціальної (загальної) дисциплінарної або (та) адміністративної відповідальності згідно з КУпАП, а у випадках, що призвели до тяжких наслідків, - і до кримінальної відповідальності.

Ключові слова: адміністративні обов'язки, адміністративні права, адміністративно-правовий статус, домашнє насильство, запобігання, компетенція, протидія, суб'єкти публічної адміністрації.

Цель статьи заключается в том, чтобы на основе ценностей естественного права, теории административного права, действующего законодательства раскрыть административно-правовой статус субъектов публичной администрации, осуществляющих предотвращение и противодействие домашнему насилию в Украине. В статье раскрыт административно-правовой статус субъектов публичной администрации в сфере предотвращения и про-

Манжос Н. В., 2019 тиводействия домашнему насилию. Он состоит в совокупности их административных обязанностей (задач) и прав, порядка и оснований возникновения специальной правосубъектности и административной ответственности за злоупотребление публичной властью или ненадлежащее осуществление предоставленной им властной компетенции по недопущению, предотвращения, противодействию и устранению ущерба, причиненного домашним насилием. Установлено, что к специализированным службам поддержки пострадавших относятся приюты для пострадавших, центры медико-социальной реабилитации пострадавших, колл-центр по вопросам предотвращения и противодействия домашнему насилию, насилию по признаку пола и насилию в отношении детей, мобильные бригады социально-психологической помощи пострадавшим лицам и лицам, пострадавшим от насилия по признаку пола, а также заведения и учреждения, предназначенные исключительно для пострадавших лиц и лиц, пострадавших от насилия по признаку пола. Определено, что юридическая ответственность субъектов публичной администрации за злоупотребление публичной властью или ненадлежащее исполнение предоставленной им властной компетенции является стандартной и неконкретной, а именно: должностные и служебные лица, признанные виновными в нарушении требований законодательства в сфере предотвращения и противодействия домашнему насилию, несут ответственность в соответствии с законом, пострадавшее лицо и обидчик имеют право на обжалование решений, действий или бездеятельности субъектов, осуществляющих мероприятия в сфере предотвращения и противодействия домашнему насилию, в порядке, установленном законодательством. Иными словами, должностные лица, субъекты публичной администрации, осуществляющие предотвращение и противодействие домашнему насилию, могут быть привлечены к специальной (общей) дисциплинарной или (и) административной ответственности по КоАП, а в случаях, которые привели к тяжелым последствиям, - и к уголовной ответственности .

Ключевые слова: административные обязанности, административные права, административно-правовой статус, домашнеенасилие, предотвращение, компетенция, противодействие, субъекты публичной администрации.

The purpose of the article is to reveal, on the basis of the values of natural law, the theory of administrative law, the current legislation, the administrative and legal status of public administration entities that prevent and counter domestic violence in Ukraine. The article describes the administrative and legal status of public administration entities in the field of prevention and counteraction to domestic violence. It consists in the totality of their administrative duties (tasks) and the rights, order and grounds for special legal personality and administrative responsibility for misuse of public authority or improper performance of the power conferred on them by their authority to prevent, prevent, counteract and remedy harm. It has been found out that specialized victim support services include shelters for 
victims, centers for medical and social rehabilitation of victims, a call center for prevention and counteraction to domestic violence, gender-based violence and violence against children, mobile psychological teams assistance to victims and victims of gender-based violence, as well as institutions and institutions dedicated exclusively to victims and victims of gender-based violence th floor. It has been determined that the legal responsibility of public administration entities for abuse of public authority or improper exercise of the power conferred on them is standard and non-specific, namely: officials and officials found guilty of violating the requirements of the legislation in the field of prevention and counteracting domestic violence in accordance with the law, the injured person and the offender have the right to appeal against the decisions, actions or omissions of the persons carrying out measures in the field of prevention and counteraction to the domestic violence, in the manner prescribed by law. In other words, public administration officials who prevent and combat domestic violence may be held liable to special (general) disciplinary or (and) administrative liability under the Code of Administrative Offenses, and in cases that have resulted in grave consequences and criminal liability.

Key words: administrative and legal status, administrative responsibilities, administrative rights, competence, domestic violence, opposition, prevention, subjects of public administration.

Постановка проблеми. Публічне адміністрування щодо запобігання та протидії домашньому насильству в сім'ї здійснюється не в якійсь безособовій формі, а конкретними органами, посадовими особами та суб'єктами громадськості. Іншими словами, публічне адміністрування щодо запобігання та протидії домашньому насильству здійснюється суб'єктами публічної адміністрації різної юридичної природи. Вони можуть бути як органами виконавчої влади, органами місцевого самоврядування, так і різноманітними суб'єктами громадянського суспільства. Усі вони беруть активну участь у заходах стосовно запобігання та протидії домашньому насильству.

Сучасне європейське суспільство характеризується гуманністю та повагою до прав і свобод людини і громадянина. Усі члени сім'ї - чоловік, жінка, діти, дідусі, бабусі та інші родичі, що проживають разом у сім'ї, мають права та обов'язки. Незалежно від статі, віку, розміру вкладу в сімейний бюджет жоден із них не може піддаватись будь-якій дискримінації. Навпаки, соціально, фізично і психологічно вражені особи в сім'ї, а саме діти, літні люди, фізично і психічно хворі потребують додаткового правового захисту та турботи.

В Україні створені певні умови для протидії та запобігання насильству в сім'ї. Зокрема, був прийнятий спеціальний однойменний закон, який визначив організаційно-правові засади запобігання та протидії домашньому насильству, основні напрями реалізації державної політики у сфері запобігання та протидії домашньому насильству, спрямовані на захист прав та інтересів осіб, які постраждали від такого насильства [1].

Посадовим особам публічної адміністрації приманна така негативна риса, як схильність до зловживання наданими повноваженнями, використання останніх для забезпечення не публічного, а особистого чи корпоративного інтересу. Щоб цього не допустити, необхідний прозорий механізм відбору і прийому на службу посадових осіб публічної адміністрації, необхідно чітко в законах прописати їхні адміністративні обов'язки, права та способи відповідальності.
Усе це разом із незадоволеністю громадян рівнем протидії та запобігання домашнього насильства в сім'ї, наявністю в цій сфері прогалин та невідповідностей обґрунтовує актуальність статті.

Аналіз останніх досліджень. Увагу проблемі запобігання та протидії домашньому насильству в сім’ї приділяли вчені правники, як: В. Бутко, Н. Дараганова, Є. Додіна, Н. Зезека, М. Кузнєцова, Б. Левківський, Ю. Лисюк, С. Мандрик, О. Пономарьов, Н. Пряхіна, О. Стець, Ю. Черняк та ін. Проте безпосередньо питання юридичної природи принципів запобігання та протидії домашньому насильству в не входили у предмет їхніх досліджень.

Мета статті полягає в тому, щоб на основі цінностей природного права, теорії адміністративного права, чинного законодавства розкрити адміністративно-правовий статус суб'єктів публічної адміністрації, які здійснюють запобігання та протидію домашньому насильству в Україні.

Виклад основного матеріалу. Категорія «адміністративно-правовий статус» у вітчизняному законодавстві $€$ невизначеною, однак в юридичній літературі з адміністративного права вона досить широко розкрита $[2 ; 3 ; 4 ; 5 ; 6 ; 7 ; 8]$.

Узагальнюючи наукові підходи до розуміння юридичної природи змісту адміністративно-правового статусу владного суб'єкта публічної адміністрації, можна прийти до висновку, що він полягає в сукупності їхніх адміністративних обов'язків (завдань) і прав, порядку та підстав виникнення спеціальної правосуб'єктності та адміністративної відповідальності за зловживання публічною владою чи неналежне виконання наданої їм владної компетенції.

Згідно із чинним профільним Законом України від 7 грудня 2017 р. № 2229-VIII до суб'єктів, що здійснюють заходи у сфері запобігання та протидії домашньому насильству, відносяться: 1) спеціально уповноважені органи у сфері запобігання та протидії домашньому насильству; 2) інші органи та установи, на які покладаються функції зі здійснення заходів у сфері запобігання та протидії домашньому насильству; 3) загальні та спеціалізовані служби підтримки постраждалих осіб; 4) громадяни України, іноземці та особи без громадянства, які перебувають в Україні на законних підставах [1].

До спеціально уповноважених органів у сфері запобігання та протидії домашньому насильству відноситься центральний орган виконавчої влади, що забезпечує формування та реалізує державну політики у сфері запобігання та протидії домашньому насильства. Це Міністерство соціальної політики України, яке координує діяльність уповноважених підрозділів органів внутрішніх справ, органів опіки і піклування із запобігання насильству в сім'ї, узагальнює відомості про насильство в сім'ї, визначає потребу в утворенні спеціалізованих установ для жертв насильства в сім'ї в регіонах, здійснює контроль за організацією і діяльністю спеціалізованих установ для жертв насильства в сім'ї, розробляє і затверджує методичні рекомендації щодо проходження корекційної програми особами, які вчинили насильство в сім'ї, приймає і розглядає заяви та повідомлення про факти вчинення насильства в сім’ї i реальну загрозу його вчинення, направляє жертв насильства в сім'ї та членів сім'ї, стосовно яких існує 
реальна загроза його вчинення, до спеціалізованих установ для жертв насильства в сім'ї [9].

Також до спеціально уповноважених органів у сфері запобігання та протидії домашньому насильству відносяться Рада міністрів Автономної Республіки Крим, місцеві державні адміністрації, в тому числі їхні структурні підрозділи, до повноважень яких належить здійснення заходів у сфері запобігання та протидії домашньому насильству [1]. Наприклад, у Старокостянтинівському районі Хмельницькій обл. Управлінням соціального захисту населення було проведено нараду-семінар у рамках Всеукраїнської кампанії «16 днів проти насильства» 3 метою привернення уваги до найбільш незахищених та вразливих груп жінок щодо запобігання та припинення до них насильства. Основними завданнями акції було привернення уваги громадськості до актуальних для українського суспільства проблем подолання насильства в сім'ї, протидія торгівлі людьми та жорстокому поводженню з дітьми, гендерному насильству, забезпечення рівних прав жінок і чоловіків, активізація партнерського руху органів державної влади, державних закладів, громадських організацій щодо проблем насильства в сім'ї та захисту прав жінок в Україні та ін. [10].

До кола спеціально уповноважених органів у сфері запобігання та протидії домашньому насильству входять і сільські, селищні, міські, районні в містах ради, їні виконавчі органи, до повноважень яких належить здійснення заходів у сфері запобігання та протидії домашньому насильству [1]. Наприклад, Бердянська міська рада провела акцію проти насильства, головною метою якої було зміцнення у громадян розуміння та обізнаності про всі форми насильства, створення соціального простору, вільного від насильства [12].

До інших органів та установ, на які покладаються функції зі здійснення заходів у сфері запобігання та протидії домашньому насильству, належать уповноважені підрозділи органів Національної поліції України, які зобов'язані (мають адміністративні обов'язки): виявляти факти домашнього насильства та своєчасно реагувати на них; здійснювати прийом і розгляд заяв та повідомлень про вчинення домашнього насильства, інформування постраждалих осіб про їхні права, заходи і соціальні послуги, якими вони можуть скористатися; взаємодіяти з іншими суб'єктами, що здійснюють заходи у сфері запобігання та протидії домашньому насильству; повідомляти центральний орган виконавчої влади, що реалізує державну політику у сфері запобігання та протидії домашньому насильству, про результати здійснення повноважень у цій сфері. Після виконання цих адміністративних обов'язків, крім загальних прав, які надаються поліцейським у сфері запобігання та протидії домашньому насильству, поліцейські мають право: виносити термінові заборонні приписи стосовно кривдників; брати на профілактичний облік кривдників та проводити з ними профілактичної роботи; здійснювати контроль за виконанням кривдниками спеціальних заходів протидії домашньому насильству протягом строку їх дії; анулювати дозволи на право придбання, зберігання, носіння зброї та боєприпасів їх власникам у разі вчинення ними домашнього насильства, а також вилучати зброю та боєприпаси в порядку, визначеному законодавством. Більш того, поліцейські можуть проникати до житла особи без вмотивованого рішення суду в невідкладних випадках, пов'язаних із припиненням вчинюваного акту домашнього насильства, в разі безпосередньої небезпеки для життя чи здоров'я постраждалої особи [1].

Також до інших органів та установ, на які покладаються функції зі здійснення заходів у сфері запобігання та протидії домашньому насильству, належать: служби у справах дітей; органи управління освітою, навчальні заклади, установи та організації системи освіти; органи охорони здоров'я, установи та заклади охорони здоров'я; центри з надання безоплатної вторинної правової допомоги; суди; прокуратура; уповноважені органи з питань пробації тощо [1].

До загальних служб підтримки постраждалих осіб належать заклади, які в тому числі надають допомогу постраждалим особам: центри соціальних служб для сім'ї, дітей та молоді; притулки для дітей; центри соціально-психологічної реабілітації дітей; соціально-реабілітаційні центри (дитячі містечка); центри соціально-психологічної допомоги; територіальні центри соціального обслуговування (надання соціальних послуг); інші заклади, установи та організації, які надають соціальні послуги постраждалим особам [1].

До спеціалізованих служб підтримки постраждалих осіб належать притулки для постраждалих осіб, центри медико-соціальної реабілітації постраждалих осіб, кол-центри з питань запобігання та протидії домашньому насильству, насильству за ознакою статі та насильству стосовно дітей, мобільні бригади соціально-психологічної допомоги постраждалим особам та особам, які постраждали від насильства за ознакою статі, а також заклади та установи, призначені виключно для постраждалих осіб та осіб, які постраждали від насильства за ознакою статі [1]. Наприклад, в Одесі відкрився Центр допомоги жінкам, постраждалим від насильства, який було створено на базі Одеського міського центру соціальних служб для сім'ї, дітей та молоді. До складу Центру входять два відділення: Одеський міський денний центр соціально-психологічної реабілітації «Розірви коло» та притулок для осіб, які постраждали від домашнього насильства та/або насильства за ознакою статі. Для проживання у притулку виділено 4 однокімнатні квартири, обладнані сучасними меблями та необхідним побутовим приладдям [13].

Що стосується юридичної відповідальності суб'єктів публічної адміністрації за зловживання публічною владою чи неналежним виконанням наданої їм владної компетенції, то згідно із законом вона $\epsilon$ стандартною і неконкретною, а саме: посадові та службові особи, визнані винними в порушенні вимог законодавства у сфері запобігання та протидії домашньому насильству, несуть відповідальність відповідно до закону, постраждала особа та кривдник мають право на оскарження рішень, дій чи бездіяльності суб'єктів, що здійснюють заходи у сфері запобігання та протидії домашньому насильству, в порядку, встановленому законодавством. Іншими словами, посадові особи, суб'єкти публічної адміністрації, які здійснюють запобігання та протидію домашньому насильству, можуть бути притягнуті до спеціальної (загальної) дисциплінарної або (та) адміністративної відповідальності згідно із КУпАП, а у випадках, що призвели до тяжких наслідків, - і до кримінальної відповідальності.

Висновки. Отже, адміністративно-правовий статус суб'єктів публічної адміністрацій у сфері запобігання 
та протидії домашньому насильству полягає в сукупності їхніх адміністративних обов'язків (завдань) і прав, порядку та підстав виникнення спеціальної правосуб'єктності та адміністративної відповідальності за зловживання публічною владою чи неналежне виконання наданої їм владної компетенції у сфері недопущення, запобігання, протидії та усунення шкоди, завданої домашнім насильством.

\section{Література}

1. Про запобігання та протидію домашньому насильству. Закон України від 7 грудня 2017 р. № 2229-VIII. Відомості Верховної Ради. 2018. № 5. ст. 35.

2. Пономарьов О. Адміністративно-правовий статус антимонопольного комітету України : автореф. дис. ... канд. юрид. наук : 12.00.07. Харків, 2010. 19 с.

3. Добкін М. Адміністративно-правовий статус виконавчих органів міських рад : автореф. дис... канд. юрид. наук : 12.00.07. Київ, 2009. 20 с.

4. Мандрик С. Адміністративно-правовий статус вищих навчальних закладів МВС України : автореф. дис. ... канд. юрид. наук : 12.00.07. Харків, 2010. 18 с.

5. Стець О. Адміністративно-правовий статус Головного управління державної служби України : автореф. дис. ... канд. юрид. наук : 12.00.07. Одеса, 2011. 19 с.

6. Додіна $€$. Адміністративно-правовий статус громадських організацій в Україні : автореф. дис... канд. юрид. наук : 12.00.07. Одеса, 2002. 21 с.

7. Зезека Н. Адміністративно-правовий статус державної служби зайнятості України : автореф. дис... канд. юрид. наук : 12.00.07. Київ, 2009. 23 с.

8. Дараганова Н. Адміністративно-правовий статус екіпажу повітряного судна України : автореф. дис... канд. юрид. наук : 12.00.07. Київ, 2009. 19 с.

9. Положення про Міністерство соціальної політики України. Затверджене Постановою Кабінету Міністрів України від 17 червня 2015 р. № 423. Верховна Рада України. 2018.

10. Порядк взаємодії суб'єктів, що здійснюють заходи у сфері запобігання та протидії домашньому насильству і насильству за ознакою статі. Затверджений Постановою Кабінету Міністрів України від 22 серпня 2018 р. № 658. Верховна Рада України. 2018.

11. Насилля в сім'ї - одна із соціальних, та найболючіших проблем сьогодення. Старокостянтинівська района державна адміністрація Хмельницькій області. 2018. URL :
Протидія злочинності: проблеми практики та науково-методичне забезпечення

http://staradm.gov.ua/2783-nasillia-v-smii-odna-z-socalnihta-nayboliuchshih-problem-sogodennia.html.

12. Бердянськ приєднається до щорічної міжнародної акції «16 днів проти насильства». Бердянська міська рада. 2018. URL : https://bmr.gov.ua/index.php?id= 800000125\&L=2\&tx_news_pi $1 \% 5 B$ Bnews $\% 5 D=14367 \&$ tx_news pi $1 \% 5$ Bcontroller\% $5 \mathrm{D}=$ News\&tx_news_pi $1 \% 5$ Baction $\% 5 \mathrm{D}=$ detail\&cHash=645f7d0c82205bdf6aef89f80e8e50f4.

13. В Одесі відкрився Центр допомоги жінкам, постраждалим від насильства. UFNPA. 2019. URL : https://ukraine.unfpa.org/uk/news/в-одесі-відкривсяцентр-допомоги-жінкам-постраждалим-від-насильства.

14. Черняк Ю. Сучасний стан та проблеми законодавчого регулювання у сфері попередження домашнього насильства щодо жінок в Україні. Вісник Академії адвокатури України. 2007. С. 34-39.

15. Про забезпечення рівних прав та можливостей жінок і чоловіків. Закон України від 8 вересня 2005 р. № 2866-IV. Відомості Верховної Ради України. 2005. № 52. Ст. 5617.

16. Про соціальну роботу з сім'ями, дітьми та молоддю. Закон України від 21 червня 2001 року № 2558-III. Відомості Верховної Ради України. 2001. № 42. Ст. 213.

17. Кузнєцова М. Ставлення до домашнього насильства в юнацькому віці: гендерний аспект. Актуальні проблеми права: теорія і практика. 2010. № 17. С. 251-255.

16. Лисюк Ю. Вплив домашнього насильства на дітей та шляхи його подолання. Вісник Хмельницького інституту регіонального управління та права. 2004. № 1-2. С. 397-399.

17. Левківський Б. Загальні проблеми юрисдикційного захисту осіб, постраждалих від насильства в сім'ї (домашнього насильства). Часопис Київського університету права. 2012. № 2. С. 171-174.

18. Пряхіна Н. Психологічні механізми уникнення кризових ситуацій працівниками ОВС під час проведення профілактики домашнього насильства та відвідування важких сімей. Проблеми екстремальної та кризової психології. 2013. Вип. 14(2). URL : С. 279-285. http://nbuv.gov.ua/ UJRN/Pekp_2013_14(2)_39.

19. Бутко В. Значення формування кривдником відчуття провини у жертви домашнього насильства. Актуальні проблеми психології. 2014. Т. 1, Вип. 41. С. 131-136.

Манжос Н. В., здобувач Науково-дослідного інституту публічного права 